\title{
Women's Entrepreneurship and Their Organization in the Context of Gender Factor: A Case Study in the Konya City
}

\author{
Esen Şahin \\ Selçuk University, Faculty of Economics and Administrative Sciences, \\ Department of Business Administration, Campus 42031, Konya, Turkey \\ Phone: 90 (332) 2233100, e-mail: eboztas@selcuk.edu.tr \\ Muammer Zerenler \\ Selcuk University, Faculty of Economics and Administrative Sciences, \\ Department of Business Administration, Campus 42031, Konya, Turkey \\ Phone: 90 (332) 2234333, e-mail: zerenler@selcuk.edu.tr

\section{Vasviye Özlem Akgün} \\ Selcuk University, Faculty of Economics and Administrative Sciences, \\ Department of Business Administration, Campus 42031, Konya, Turkey \\ Phone: 90 (332)8340306, e-mail: ozlemakgun@selcuk.edu.tr
}

\author{
Doi:10.5901/mjss.2013.v4n10p737
}

\begin{abstract}
Scientific and technological advancements in our contemporary world have substantially altered dynamics of competition in parallel to the production systems. These changes have brought new dimensions to the entrepreneurship as well as business administration fields. The differences in social responsibilities based on gender have been part of people's life from its beginning to the end. The entrepreneurship understanding which has presented great developments in all over the world since 1980s has been interested in by women as much as men recently. In our present era in which women's participation into the business life accelerated and accordingly their rate within the total labor is continuously rising, economic and social development process and fast paced advancements in science and technology have evolved women's role in society and turned them into primary players in the business life. Organization is one of the essentials of living social life based on various reasons. In terms of social context, organizations in the forms of sociological, civil or labor unions have always been part of people's life. In the aspect of entrepreneurship, movement of entrepreneurs within an organization can be viewed the result of their way of business and requirement of competition and our contemporary world. The purpose of this study is present that women who naturally own different perspective in many areas than men add different taste and success into the business life through their equalizer factors in both social relationships and private life; and to draw women entrepreneurs' general profiles and their organization in the context of Konya City case.
\end{abstract}

\section{Introduction}

The period of 1990s has witnessed revolutionary developments in the business life. Whereas the organizations of the industrial society exhibit a structure relying on labor force ergo male-dominance, as a result of the evolutions caused by the developments experienced in the recent two decades which is referred as the information age, the labor prototype has been transformed toward being "women-dominant". In this structure which hosts information and service industries in its foundation, intensive application of technology has created more women labor in business life.

It is widely recognized that the entrepreneurship phenomenon does not relate with gender. Thus, as it was happening before, the business life is not ruled only by men anymore. Increasing number of women is participating into the business life and they regenerate the rules again. With their natural born characteristics, women are terminating male dominance in the business life. Their emotional and sensual superiorities in their nature and intensify through their maternal role, such as communication talent, emotional intelligence used appropriately, patience, compassion, emphatically approach, capability to benefit at full extent from their senses, talent for resourcing, dispute management ability, creativity, organization-time management and etc. reflect over their attitudes and accordingly bring women 
managers and entrepreneurs success in business life (Berberoğlu, 1989). Women entrepreneurs continue their success in the business life for certain by making movement under organized structure.

\section{Entrepreneurship \& Gender Factor in Entrepreneurship}

This section considered entrepreneurship and gender factor in entrepreneurship subjects in a conceptual perspective and their scopes were explained.

\subsection{Definition and Scope of Entrepreneurship}

The entrepreneurship term was derived from the French word "entreprendre" which means "a person, who undertakes a duty, takes risk, do business". In the beginning, the entrepreneurship concept was embraced in parallel to this meaning (Tekin, 2010). Then, the concept incurred a significant evolution process during the $18^{\text {th }}$ century and was adopted to refer inventors of that era. As the inventors who were perceived as a creative society of this era were being included in the category of group in need for capital, the capital providers were described as venture capital funders (Hisrich et al., 2005). In the ends of the $19^{\text {th }}$ century and in the first half of the $20^{\text {th }}$ century, for the term of entrepreneur, a managerial role was assigned. In this period, entrepreneurs watch out their individual interests and supplied funds to compensate costs.

The entrepreneurship concept was started to be used as special term for new organization and attempts to establish business regarding economic and business management activities which is referred as "enterprise" after the beginning of the $20^{\text {th }}$ century. In the second half of the $20^{\text {th }}$ century, entrepreneurs were the persons who challenge the current production methods, and generate innovative and creative models based on the understanding derived from their roots in entrepreneurship definitions of the $18^{\text {th }}$ century. One of the essential factors of the current entrepreneurship definitions is innovation. Together with the change occurred in competitive environment and globalization process, the definition of entrepreneurship includes elements of taking more risk, catching up with novelties, taking advantage of opportunities, and actualizing this process.

Entrepreneurship means that having competency to sense opportunities arising within the current environment, to generate projects from these senses, and to make these projects actualized so that they can create fortune and make the human life more convenient. Entrepreneurship is the driver of the economic growth and development. It is resource of the innovation and creativity. Entrepreneurship introduces new resources and technologies with the society; and by this means, the resources which have not been exploited, or were not utilized thoroughly before are gained into the economy and thus overall production increases.

Entrepreneurship has always played key role in economic and social development. Entrepreneurship is recognized as one of the resources of society for sustainable economic and social development. There is direct relationship between the numbers of entrepreneurs in a country and creating new job opportunities and accordingly providing solution for unemployment problem, gross domestic product, social welfare and life standard. A newly established or reorganized company would positively affect the employment volume of a country; and economic development rate would gain a positive momentum.

After all is said and explained, an entrepreneur can be defined as a person who exploits the opportunities in the market and takes risk by bringing production factors such as capital, natural resources, and labor so as to produce goods and services. Entrepreneur is a person who makes innovation and enhancements by taking risk. A successful entrepreneur is a person with capability to sense opportunities arising in the present environment, to generate projects based on these senses, to make these projects actualized, and to make human life better and convenient by generating welfare.

\subsection{Gender Factor in Entrepreneurship}

In our contemporary business life in which the competition dynamics have been radically evolved, not only business areas and business styles have been influenced, but also the profiles of the business owners have been affected. These changes add new dimensions into many areas in business administration and as well as entrepreneurship field.

Along with the historical process, there are different roles have been assigned to women and men. Traditionally, while it was thought that some particular jobs were more suitable for men, some others were found appropriate for women. Although the gender-based roles were first defined and the expected roles were conceptualized by the society, 
because these roles conveyed to women since their childhood through the socialization process, they have been internalized and adopted by women. Furthermore, these social roles have transformed into attitudes that are adopted and considered as stationary position that cannot be altered by women themselves (Hancl, 2004).

There are many points between women and men entrepreneurs in common. However, there are numerous different dimensions due to both gender-related reasons and social judgment values and upbringing. These differences become clear especially in terms of motivation, business senses and occupational experiences.

The existence of social gender patterns also causes to women and men to undertake occupational roles due to their gender. Studies regarding gender roles within the society show that the characterizations that are assigned to men reflect their competency and capability for achievement. These characterizations consist of being independent, active, objective, self-confident, ambitious, challenging and rationalist. Characteristics that have traditionally been inscribed to women are that kindness, emotional, sensitive and understanding (Mueller and Dato-On, 2007). Basically, the main difference between man and woman entrepreneurs is the gender difference. Women and men entrepreneurs could coincide with different circumstances or they can perceive and analyze same conditions in a different ways. To that end, women can be differentiate from men in terms of their business starting motives, difficulties that they experience when they start and continue their business, establishment, management activities for business, design and development activities, targets and way of administering their business (Erdoğan, 2008; Verheul et.al., 2006).

The dispersion in the social responsibilities based on gender is phenomenon that starts from individuals' birth and continues till its end. Women who are observed that they are experiencing a great breakthrough in all over the world progressively increase their weight I business life. It can be seen that women could prefer establishing their own businesses so that they can use their own talents and competencies in addition to the other reasons. It could be seen that women, who naturally could have quite different point of view compared to men, is capable of adding various taste and success into the business life through their talent to apply equalization characteristics to their business life as they do the same to their social life.

In recent years, it is known that there has been substantial increase in women's participation rate to the entrepreneurship activities and they have accomplished numerous projects in entrepreneurship field with or without an organization. However, it was concluded that the level of having their own business has not been sufficient level yet when it is compared with men's rate. Majority of the studies conducted in this subject across various societies present that the probability of men's indulging in entrepreneurship activities is higher than the women's probability rate (Zhang et al., 2009; Mueller and Dato-On, 2007).

\section{Women Entrepreneurship: Its Definition and Scope}

It is observed that gender has been an important factor in the formation of social status in societies from past to our present era. Legal, economic and social structures of countries determine women's role and expectations within the society. There are data regarding women labor force is at least half of the men work force in many countries in the world. The most significant effect lying underneath of this fact could be presented as insufficient education models that is not suitable their main purpose (Rahman, 2010). Moreover, especially in developing countries such as Turkey and in underdeveloped countries, women may encounter several obstructs which prevent them to develop business because of existing factors such as traditions and customs which are not included in written codes. Together with the globalization, accelerated development in information and communication technologies has given women freedom in many courses of the daily life and contributes increasing number of women entrepreneurs as well.

Enduring within the society with an entrepreneur role would provide women more autonomy, freedom, chance to self-realization and acquire future targets compared to their position in other positions in business life. Hence, women could have a voice within the total employment in terms of using the resources in an optimal way, being success in social relationships, channeling experiences that they obtained in their business to the other sectors by making short or long term business plans. Furthermore, entrepreneurship also provides women chance to determine their own fate and to overcome their dependency.

When the literature concerning entrepreneur women was investigated, obtained definitions stress following points (Tekin, 2010):

- Who has a business established under her name in a place other than home,

- Who is working in this entity alone or under a partnership and/or with others employed,

- Who contacts with public and private institutions about her business,

- Who makes plans about the future of her business, 
- Who has rights over the investment and usage of the income generated from the business,

- Who takes the whole risk that is incurred from the business.

Today, women assert their strengths in various areas such as economy, art, science, politics, social life, press, local administrations, law, non-government organizations and foundations; and they constitute significant majority in these areas. Besides, the increment in the number of women in a great many professional occupations has reach serious levels. Women who have manage to climb up to the top of pyramids of decision makers and who succeeded to establish their relationship network have proven themselves in the businesses that they entered as an entrepreneurs (Cem and Ünal, 2006).

Women's success in entrepreneurship depends on their self-confidence; and based on this confidence, it relies on their capability to take risk. Creative, prudential, open-minded, talented for providing solution and mediating women would compete by taking private responsibility and eventually achieve success. Woman who could defend their case, lead, use her authority, and good at their social relationships would have a voice in social and in business life as an individual entrepreneur.

\section{Organization in Entrepreneurship}

The significant welfare development exhibited by the societies from the past till today is the result of their movement through cooperation and division of labor on the largest extent. It is observed that people always come together under various names so that they live more convenient and comfortable life in a general perspective, and to accomplish their certain targets more productively in an efficient way in private perspective. The process of presenting desire to act together for a certain purpose by several people groups and making division of labor and cooperation to that purpose is called "organization" in general.

Organization is sort of unifying factor for people to live mutual social life based on various reasons. In the context of society, organizations in the forms of sociologic, civil or labor union have always been part of human life. When it is considered in general, all sorts of effort and action to organize through the society is an entrepreneurship activity. The whole process that starts with initiative of a person or persons and continues with the participation of other society members, financial resources and opportunities to embark a new action for "organization" and to finalize it based on its initial purpose is called "entrepreneurship".

There is great similarity between the concepts of organization and entrepreneurship in terms of completing each other and mutual interaction. Entrepreneurship is the process of design of a new condition which is not present in the current situation; and mobilization of all means and resources to that end and taking all associated risks. The subfunction of the entrepreneurship process, organization is to generate compound by bringing relevant material and emotional resources to actualize the intended and designed new condition.

Entrepreneurship, as concept with business administration background, is bringing current production factors and various resources together as new process so as to produce new goods and/or services, to find new markets, and to generate new organizations. Under normal circumstances, as a potential opportunity, each average human being possesses entrepreneurship and organization capabilities at various levels. However just a limited number of people in societies can deploy their talent in entrepreneurship and organization. Societies' advancement and success in economic, technological, military, social, politic and cultural areas are closely related with effective and successful entrepreneurs and their existed organizations, businesses, and other entrepreneurs' activities. In this context, through available human resources and various resources, organization of several activities and managing manufacturing activities is an outstanding and qualified movement and organization style that is motivated with desire for independency rather than being one of the average and ordinary personality characteristics.

\section{Organization of Women Entrepreneurs: A Case in Konya City}

Konya is successful city in achieving certain level in industry and commerce sectors. In this success, a collaboration factor which is rooted back in ancient "ahilik" tradition have been played significant role. Konya entrepreneurs have continued their activities by monitoring world commerce closely, paying attention to high-tech developments, by following a profile aiming to actualize a Konya vision thorough innovative approaches. Konya has been contributed to the Turkish economy since its foundation; and was managed to guarantee its ambitious future based on its activities in our present era. 
Konya is among the first row of cities in Turkey in terms of having highest number of Small and Medium Sized Businesses in its organized industrial zones and private industry zones. The existence of individual-oriented entrepreneurship and thus small-sized incorporation can be mentioned.

In Konya city, among the women entrepreneur profile, it is one of the conclusion of the study that women entrepreneurs who are called "career entrepreneurs" in terms of occupational groups and who establish their own business and making their own career following an occupational training so as to be determine their own purpose, targets, needs and requirements (Şahin, 2006). The reasons behind the limited number of women entrepreneurs as business owners, company managers, industrialists and freelance workers are that their boredom that they experience when they need to take risk and undertake responsibility. Furthermore, it was observed in general that in the business establishment process, women entrepreneurs carry some concerns, experience problem in gathering required capital, and they experience conflict between roles which are assigned them by the society and the roles required by women entrepreneurship.

After 1980s, according to the studies investigating women entrepreneurs, as it is seen many developed and developing countries, women experience issues both that are faced by entrepreneurs in general and that additional other issues just because they are women (Tekin and Boztaş, 2004). By means of supports to reduce bureaucratic limitations toward their access to required capital, loan and credit resources, training in administration and technical subjects, providing social and cultural activities that develop their personal enhancements and etc., it would be possible for the women entrepreneur phenomenon to reach to the respected point where it deserves within the society (Kutanis, 2004).

It is vitally important to remove obstacles before women that prevent them from establishing and developing their own business; and to create a fare playground for women business owners in terms of a strong entrepreneurship sector; and it plays an important role in national growth strategies. Women business owners generate new areas in entrepreneurship activities and they carry potential to be important player in the economy based on information.

As a result, women will eventually contribute removal of regional economic differences by playing more significant role in different occupations and by developing their entrepreneur characteristics. It is essential that women should make their movement through organization to overcome problems that they face in terms of entrepreneurship.

When we compare Konya city with the previous years from the angle of women entrepreneurship, it was observed that there have been significant developments. Under the effects of several factors, it was determined that number of women who established their own business has been increasing day by day. In the meantime, it was observed that women entrepreneurs have been organized so as to find solutions for financial and non-financial problems and to have access to various incentives through the supports of different institutions and organizations.

In the Konya city case, the studies conducted regarding women entrepreneurs directed us to the samples of "Women Entrepreneur Board (KAGIK)" and "Konya Women Entrepreneur Desk (KAGIM)". Therefore, organization of women entrepreneurs was taken based on the samples of the KAGIK and the KAGIM in this present study.

\subsection{Women Entrepreneur Board (KAGIK)}

The Women Entrepreneur Board (KAGIK) which was founded in Konya under the Turkish Union of Chambers and Commodity Exchanges (TOBB) is an active board in Konya and founded along with the plan and policy of TOBB to obtain a women entrepreneur board in each city. To that end, Konya Women Entrepreneur Board (KAGIK) was structured in March 2008 and started its activities with 40 members; and still continues to operate.

The main purpose of this board is to carry out studies to develop both quantity and quality of women employment. The coordination of this board was provided by the TOBB. The Konya KAGIK has been direct supporter of the Women Entrepreneurs Desk (KAGIM) which was founded to support women who has motivation to be an entrepreneur in the Konya city under the EU project; and both organizations have performed successful projects jointly. In this framework, there have been various trainings and seminars arranged for women entrepreneurs. These mutual activities are currently implemented successfully.

Among the main purposes of the Konya Women Entrepreneurs Board (KAGIK) which develops strategic partnerships, promotes and handles experience sharing, provides opportunity to competitors to know and compare each other, there is one to strengthen business networks among similar women initiatives as well. In terms of activity organization and sharing the best experiences, the business networks provide a crucial resource since they offer communication channel for support and a valuable training mean. Furthermore, extended business networks will also help to reach all sects of the society and to make activities more convenient for determined purposes (http://www.kto.org.tr/konya-women-girisimciler-board-382s.htm, A.D.: 2013 May). 


\subsection{Konya Women Entrepreneur Desk (KAGIM)}

Konya Women Entrepreneur Desk (KAGIM) which adopted a motto "Turn your dreams into an idea; then turn your ideas into your business" is support unit that continues its operations under Civil Society Dialog - the EU - Turkish Chambers Forum, the EU - Turkish Chambers Partnership Grant Program which is referred as "Strengthening Women - Supporting Women Through Establishing Partnerships in Terms of Capacity and Service in Konya Women Entrepreneurship" and jointly conducted by the Formaper Agency bound to both Konya Chamber of Commerce and Milano Chamber of Commerce with the project number of CFCU/TR0604.03-13.

General targets of the KAGIM Project are given below:

- Increasing number of women entrepreneur in Konya by encouraging women to establish business,

- Supporting existing women entrepreneurs and promoting entrepreneurship against unemployment,

- Establishing a communication network among women entrepreneurs,

- Correcting negative women entrepreneur perception,

- Strengthening the collaboration between Turkish and the EU Chambers of Commerce.

The KAGIM started its operations to embrace a strategy which monitor women who want to establish their business and who already have business as an entrepreneur. The solid purpose of this strategy is to increase number of women entrepreneurs and accordingly to support existence and development of the women owned KOBis; and to generate and offer high-quality business development services by promoting women to set up their own businesses in the Konya City (http://www.kagim.org.tr, A.D.: 2013 May).

\subsubsection{The KAGIM Services}

The KAGIM provides services for information, training and consulting for women entrepreneurs. Within the targets under the scope of these services offered, there are aims to reveal and develop the entrepreneur sides of women as well. The KAGIM gives supports under these main headlines: under the "Information" title: women and economy, sectorial information, incentives and supports, the European Union Grant programs, bureaucratic processes; under the "Training" title: start-up programs for the women who want to be an entrepreneur, and entrepreneurship trainings and training booklets under the capacity development programs for entrepreneur women; under the "Consulting" title, a support desk service, experience sharing group and monitoring services are given.

When these services and feedbacks taken from the conducted activities are investigated, it was seen that the KAGIM provides a bridging function in Konya for women entrepreneurs in the extent of guidance for their business life, in their self-development from the social aspect; and in undertaking active and successful roles in social projects.

\section{Conclusion}

Enterprise and entrepreneurship concepts are the ones that have succeeded to carry out their position in business life to the new dimensions day by day from past to our present time as one of the primary business dynamics. Women entrepreneurship is a concept that has arisen as a result of movement of women into entrepreneurship activities and increment of the importance of their role in women entrepreneurship activities. Women carried some of their natural characteristics, emotions, ideas and talents which differentiate them from the men into the business life and succeeded to be pointed out in the entrepreneurship field based on their creative and innovative point of view and different management styles. It is undeniable fact that sound of women's heels has been heard in the entrepreneurship area in our country and in the world more than ever.

Women entrepreneurship and organization of these entrepreneurs are two concepts which came to forefront in recent years and it was seen that they are used in the literature together in the literature.

In this present study, the women entrepreneurship subject was considered over the case study of the Konya city in the context of organization of entrepreneurs. Conducted studies exhibited that women entrepreneurs have crucial contributions in actualizing their business opinions, being motivated, being more conscious and in their success. From this point of view, the study was structured based on concrete samples that bring phenomenon of women entrepreneurs and organization of entrepreneurs in the Konya city. The researches made at this point carried this study to the samples of the "Women Entrepreneur Board (KAGIK)" and the "Konya Women Entrepreneur Desk (KAGIM)".

In the context of organization of entrepreneurs, the KAGIK and the KAGIM provide support in fields of entrepreneurship training, incentives, communication network, information share and motivation subject by bringing 
women entrepreneurs together. There are also successful studies in Konya on the levels of NGOs, organizations, foundations, and individual activities as well. It is observed that foundations, women organizations, training institutions, private-public institutions and organizations in the Konya city contributed to the social change and evolution through social activities such as poverty, education, maternity and child health, human rights, nature protection and sustainable development. It is also known that some women entrepreneurs individually contribute these activities. Although these activities have significant consequences, unfortunately they do not carry a character to be considered under the social initiative activity that leads the society.

As a result of this study which relies on the aim to draw a general profile regarding organization of women entrepreneurs in the Konya city, it was concluded that among the causes of problems that the women entrepreneurs encounter in their business life, faults in society's economic, social and cultural structure can be mentioned. It is thought that each step taken toward overcoming these problems by means of organization of women entrepreneurs will provide positive contribution to women entrepreneurs. For women who constitute half of the society to form a well-balanced integrity with men the other half, various and urgent precautions should be taken.

The women entrepreneurship has crucial importance in economic and social development. If women entrepreneurs are given diverse opportunities in business life, and if limitations before them in entrepreneurship are removed, this will be beneficent for both them and for the people who are employed by them. Moreover, participation to the labor force will eventually strengthen women's position in the society and affect their development level and prevent injustice in income distribution. From this point of view, the public organizations and non-government organizations must show great effort to promote women entrepreneurship. In addition, contributions of universities and faculty members are required to guide ongoing studies and to train women entrepreneurs. A world in which women can mobilize their individual abilities and potentials for the good of humanity will be more democratic and more independent for both women and men. As the private entrepreneurship which relies on competition and that is referred as "private enterprise" develops in a country, that country's economic welfare will develop accordingly.

\section{Referances}

Berberoglu,1989, "Women Yöneticiler: İş Hayatındaki Yeri ve Sorunları", Eskişehir Anadolu Üniversitesi 9. 9. B. F. Dergisi, Cilt:Vii, Sayı:1, s.305.

Cem, Ünal, 2006, "Türkiye'nin En Güçlü Womenları", Forbes Dergisi, Sayı: 4, s.84.

Erdoğan, 2008, Entrepreneurship ve Kobiler: Teori ve Uygulama, Ekin Basım Yayın Dağıım, Bursa,s.451.

Hancı, 2004, Girişimcilikte Cinsiyet Faktörü ve Kadın Girişimciler Üzerine Bir Araştırma. Yayınlanmamış Yüksek Lisans Tezi, Sakarya Üniversitesi Social Bilimler Enstitüsü, Sakarya, s.17-18.

Hisrich, Peters ve Shepherd, 2005, Entrepreneurship, 6th Ed., Mcgraw-Hill International Edition, New York, p.10-19.

Kutanis, Hanci, 2004, "Kadın Girişimcilerin Kişisel Özgürlük Algılamaları", 3. Ulusal Bilgi, Ekonomi ve Yönetim Kongresi, Osman Gazi Üniversitesi İ.I.B.F., Eskişehir. Http://libf.Ogu.Edu.Tr/Kongre/Bildiriler/11-02.Pdf, s.461

Mueller, Dato-On, 2007, Gender-Role Orientation as a Determinant Of Entrepreneurial Self-Efficacy, Journal Of Developmental Entrepreneurship, 13 (1), p.15.

Rahman, 2010, "Hathay Bunano Proshikshan Society (Hbps): A Social Business Enterprise For The Rural Poor Women", Gim Case Study No B064, United Nations Development Program, New York, p.26.

Şahin, 2006, Kadın Girişimcilik ve Konya İlinde Kadın Girişimcilik Profili Üzerine Bir Uygulama, Yayınlanmamış Yüksek Lisans Tezi, Selçuk Üniversitesi Social Bilimler Enstitüsü, Konya, s.111.

Tekin, 2010, Hayallerin Gerçeğe Dönüşümü; Girişimcilik, 5. Basım, Günay Ofset, Konya, s.318-325.

Tekin, Boztaş, 2009, "Kadın Girişimciler ve Karşıllaştıkları Sorunlar", I. Kobiler ve Verimlilik Kongresi, İstanbul, s.195.

Verheul, Van Stel and Thurik, 2006, Explaining Female and Male Entrepreneurship at The Country Level. Entrepreneurship And Regional Development, 18 (2), p.97-105.

www.kagim.org.tr

www.kto.org.tr

Zhang, Zyphur, Narayanan, Arvey, Chaturvedi, Avolio, Lichtenstein and Larsson, 2009, The Genetic Basis of Entrepreneurship: Effects of Gender And Personality, Organizational Behavior and Human Decision Processes, p.98. 